\title{
Primary Teachers' Perceptions on ICT Integration for Enhancing Teaching and Learning through the Implementation of One Laptop Per Child Program in Primary Schools of Rwanda
}

\author{
Sylvestre Munyengabe ${ }^{1}$, Zhao Yiyi ${ }^{1}$, He Haiyan ${ }^{1 *}$, Sabin Hitimana ${ }^{2}$ \\ ${ }^{1}$ School of Education, Beijing Institute of Technology, Haidian District, Beijing, P. R. CHINA \\ ${ }^{2}$ School of Software Engineering, Beijing Institute of Technology, Haidian District, Beijing, P. R. CHINA \\ Received 3 May 2017 - Revised 3 September 2017 - Accepted 20 September 2017
}

\begin{abstract}
Identifying teachers' perceptions for integrating ICT into teaching and learning processes through the implementation of One Laptop Per Child (OLPC) program in primary schools of Rwanda was the main target of this study. The study employed qualitative approach where thirty primary schools' teachers participated into this study through interviews and group discussions designed for the research questions. Questions and discussions were related to benefits of ICT in education; requirements to integrate ICT into teaching and learning practices; challenges hindering the implementation of OLPC program and the contributions of different stakeholders for implementing OLPC program in primary schools of Rwanda. Through thematic analysis of data, the program was found to be influential to teachers, learners and stakeholders of primary schools in Rwanda. In order to be fruitful, the integration of ICT through implementation of OLPC program requires to help teachers to acquire skills related to Technological Pedagogical Content Knowledge (TPACK). The study also suggested different solutions and strategies related to all identified challenges.
\end{abstract}

Keywords: ICT integration, teaching and learning, one laptop per child program, technological knowledge

\section{INTRODUCTION}

Information Communication Technology (ICT) was proven to be influential in everyday activities of different organizations (UNESCO, 2015). ICT skills were found to be necessary among the required skills of 21 century (Burkhardt, et al., 2003). The adoption of using ICT tools in education enhanced teaching and learning processes in different forms and levels of education (UNESCO, 2003; Vandeyar, 2015). Rwanda, one of developing countries like many others have adopted the integration of ICT into their education systems. Rwanda was targeting to prepare the population to be familiar with ICT' use, so that, every learner should attain the minimum required quality education (Farrell, 2007). Because of Rwanda 2020' vision, the country has developed its will to develop citizens through the integration of ICT in all levels of its education system (Rwanda Vision 2020, 2000). The integration of Information and communication Technology (ICT) Policy in all levels of education in Rwanda was the one of the major goals which aims to raise the standards of ineffective centralized education system (Kayisire \& Wei, 2016; Farrell, 2007).

Not only the education system that the government targeted, they also targeted the goal in which the country will achieve middle income status by 2020 based on an information-rich, knowledge-based society and economy, achieved by modernizing its key sectors using ICT (Farrell, 2007). There are a number of factors that prevent the use of technology in education, such as shortage of training, time, equipment and materials (Mtebe \& Raisamo, 2014; Muhametjanova \& Cagiltay, 2016; Porter \& Graham, 2016; Tarus, 2015).

The success of ICT integration in different corners, particularly in primary schools, the country was requiring the combination of effort from the government and different stakeholders (UNESCO, 2015). One of many different

(C) Authors. Terms and conditions of Creative Commons Attribution 4.0 International (CC BY 4.0) apply. 


\section{Contribution of this paper to the literature}

- Integration of ICT into teaching and learning processes is influential for teachers, learners and other stakeholders in education.

- The implementation of One Laptop Child program is a way that can be used to integrate ICT in education for developing countries.

- Good teachers' perception, collaboration, motivation, problem solving are crucial for implementing any education policy and enhance teaching and learning processes.

initiatives that Rwanda had tried to increase the use of ICT in its education system was to reform the existing curriculum by introducing ICT through the policy. Through the ministry of education, a project called "One Lap Top per Child program" was initiated and more than 200,000 small laptops were distributed to the public primary schools (RwandaVision 2020, 2000).

Despite, the government's will of promoting ICT use; the implementation of OLPC program in primary schools of Rwanda requires the intervention of different factors attached to learners, teachers, parents, teaching environment and the effective school leadership (UNESCO, 2015; Kayisire \&Wei,2016). Few researches were carried out to investigate the progress of the implementation of OLPC program into teaching and learning processes in primary schools in Rwanda. However, the criticisms regarding the implementation of ICT policy were raised (Mukama \& Andersson, 2007). According to Mukama, the deployment of computers in schools was different from what was written in the plan due to the expectation of getting funds from donors. The schools' geographical location was also found to be one of the cause of lacking the electricity where in the different remote countryside, many schools can't have the access to this program unless the electricity is available (Mukama \& Andersson, 2007). The paper attached much important to the integration of ICT in teaching and learning in primary schools of Rwanda which is built upon primary teachers' perceptions and different requirements.

\section{THE EFFECTIVENESS OF ICT IN EDUCATION}

ICT is one of the potential and powerful tools for extending educational opportunities (UNESCO, 2003). Knowledge transferred through the means of ICT tools were shown to be influential for both formal and non-formal education (UNESCO, 2015). The major important characteristic of ICT is the ability to transcend time and space (Tarus, 2015). The use of ICT tools makes possible asynchronous learning, or learning characterized by a time lag between the delivery of instruction and its reception by learners (Bornman, 2016). The importance of ICT use in teaching and learning processes is largely expressed by online course materials, where for example, teaching and learning can be accessed 24 hours a day, or times without limitations (Tarus, 2015).

Besides, certain types of ICT tools, such as teleconferencing technologies, help instruction to be received simultaneously by multiple learners geographically dispersed (Muhametjanova \&Cagiltay, 2016). With the means of ICT tools, teachers, learners and many others who will take the use of the tools no longer have to depend solely on printed books and other materials in physical media housed in libraries (Mukama, 2007). Internet and the World Wide Web play a vital role in disposing different types of learning materials to unlimited spaces without any restriction of people and without any time constraints (Tarus, 2015). The use of ICT tools is crucial to increase the quality education largely in developing country or in some developed countries with limited and outdated library resources (UNESCO, 2003). Besides all of these cited influences of ICT in education, it was also important in facilitating communication between resource persons, mentors, experts, researchers, professionals, business leaders, and peers all over the world (Asongu \& LeRoux,2017).

\section{INFLUENCE OF ICT IN TEACHING AND LEARNING}

Teaching and learning are complex processes requiring multiple tasks, efforts and flexibility of teachers and learners (Jaarsveldt \& Wessels, 2015). According to Stones (1966), teaching refers to knowledge transfer while learning refers to changes that would be taken into individuals' behavior. The importance of ICT in teaching and learning processes is undoubtedly because ICT may be looked as "mediator or a bridge" among factors intervening in teaching and learning (Vandeyar, 2015).

The model of teaching and learning processes as suggested by Mcllrath and Huitt (see Figure 1) suggested the influence of community, schools policies, state policies and family background to teachers or learners' characteristics in teaching and learning activities (Mcllrath \& Huitt, 1995). During the teaching and learning processes, the interaction between teachers and learners was found to be influential in increasing teaching and learning processes (McIlrath \& Huitt, 1995). The use of ICT tools in teaching and learning goes in hand with different changes such as teachers' and learners' roles in teaching and learning environment as well as changes in 


\section{TEACHING-LEARNING PROCESS}

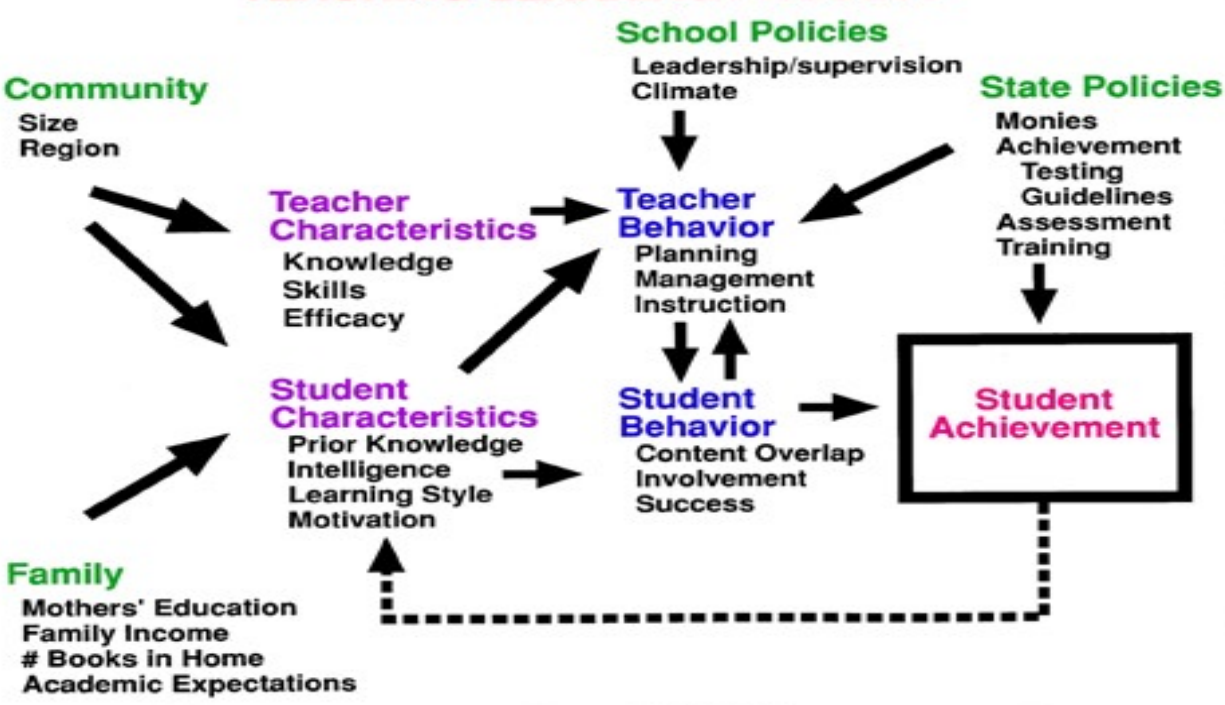

Figure 1. Summary of Teaching and Learning Process proposed by Mcllrath, D., \& Huitt, W. (1995)

curriculum delivery and applications (Resta, 2002; Tarus, 2015; Vandeyar, 2015; Bornman, 2016 and Asongu \& LeRoux, 2017).

\section{BENEFITS OF ICT FOR TEACHERS}

Teachers play a vital role in teaching and learning process (Alesandrini, 1981). The introduction of ICT in teaching and learning processes has been very influential to teachers as ICT facilitates teachers to share teaching resources (Jaarsveldt \& Wessels, 2015); expertise and advice (UNESCO, 2015; Tarus, 2015). ICT tools remove the barrier and allow flexibility in what, how, when and where to carry out all teaching and learning activities (AltınayGazi \& Altınay-Aksal, 2017). Through ICT's application, teachers' skills, confidence and enthusiasm are increased. ICT in education serves as a teachers' powerful tool for easy planning and content preparation to be delivered (Burkhardt, et al., 2003). From ICT's applications, teachers are benefiting the full access to up-to-date pupils and school data, anytime and anywhere (Muhametjanova \& Cagiltay, 2016; UNESCO, 2015).

\section{BENEFITS OF ICT FOR LEARNERS}

ICT tools were found to be not only significant for teachers but also facilitate learners in their everyday-learning activities (Bornman, 2016; Asongu \& LeRoux, 2017). Integration of ICT helps in more focused teaching, tailored to students' strengths and weaknesses, through better analysis of attainment data (Andersson, 2006; UNESCO, 2015).

Through ICT tools learners get the benefit from the improved pastoral care and behavior management through better tracking of students (Anderson 2006). Another significance role of ICT' gains for learners is expressed by understanding and analytical skills, including improvements in reading and comprehension (UNESCO, 2003; Jaarsveldt \& Wessels, 2015). According to UNESCO (2015), ICT tools help learners develop their writing skills, fluency, originality, flexibility and elaboration. Learners are encouraged to carry out independent and active learning, and self-responsibility for learning (Muhametjanova \& Cagiltay, 2016). The current findings of Asongu \& LeRoux (2017) showed that the use of ICT tools increases the learners' interests of learning and doing research. The similar study of Tarus (2015) showed how ICT tools help learners to have opportunities of addressing their work to an external audience which allows the fully opportunities to collaborate on assignments with people outside or inside school.

\section{BENEFITS OF ICT FOR PARENTS}

The teaching and learning model of McIlrath \& Huitt (1995) shows the contributions and influences of different components intervening in teaching and learning activities. ICT tools facilitate the easy communication with teachers and increase higher quality student reports in a more legible, detailed and better presentation. Parents have a greater access to more accurate attendance and attainment information of their children (UNESCO, 2015). The integration of ICT into teaching and learning activities allows parents to be more likely engaged in the school 
community which presents a positive impact across a very wide range encountered in the aspects of school life (UNESCO, 2003; Kayisire \& Wei, 2016).

\section{THE USE OF ICT HELP TO IMPROVE THE QUALITY OF EDUCATION}

ICT tools can enhance the quality of education in different ways: (1) to increase learner's motivation and engagement, (2) to facilitate the acquisition of basic skills, and (3) to enhance the teacher's training. The use of ICT in teaching and learning is considered as the transformational tools and if these tools are used adequately, they can promote and the shift to a learner-centered method of learning (UNESCO, 2015).

Learning motivation: According to Altınay-Gazi \& Altınay-Aksal (2017) and Tarus (2015), ICT tools, such as videos, television and multimedia computer software that combine text, sound, and colorful, moving images can be used to provide challenging and authentic content that will engage the student in the learning process. When learners are motivated to learn through the use of ICT tools, their intentions and morale of self-engagement are maintained higher (Emeh \& Agbor, 2003). Interactive radio likewise makes use of sound effects, songs, dramatizations, comic skits, and other performance conventions to compel the students to listen and become involved in the lessons being delivered (Altınay-Gazi \& Altınay-Aksal, 2017).

Facilitating the acquisition of basic skills: The use of ICT tools helps in transmission of basic skills and concepts that are the foundation of higher order thinking skills and creativity through drill and practice (UNESCO, 2003; Altınay-Gazi \& Altınay-Aksal, 2017). Teachers, learners and many others may gain knowledge from educational television programs which most of them were computer -based learning which enhance the acquisition of skills through repetition and reinforcement (UNESCO, 2015).

Enhancing teacher's training: ICT tools play a vital role in improving the access to and the quality of teacher training. It is possible to train many teachers together by using different means of ICT tools where teachers from different area may attend and gain skills to develop their teaching professions (Tarus, 2015).

\section{WHAT ARE THE SKILLS REQUIRED FOR INTEGRATION ICT IN TEACHING AND LEARNING?}

Teachers' role in curriculum implementation requires certain level of knowledge to integrate the content efficiently which might be taught (UNESCO, 2015; Sekoaila et al., 2016). Similar to other subjects which are disseminated by teachers, the integration of ICT into teaching and learning processes requires teachers to acquire a certain level of different skills to handle all challenges attached to the integration of ICT into teaching and learning processes (Igbo \& Imo, 2017). The theoretical framework of Technological Pedagogical Content Knowledge (TPACK) was introduced for understanding the teachers' knowledge required for integrating ICT into teaching and learning processes (Koehler et al., 2014; Mishra \& Koehler, 2006 and Schmidt et al, 2008).

As indicated in Figure 2, teachers require different knowledge for better integrating ICT into teaching and learning processes (Mishra \& Koehler, 2006; Schmidt et al, 2008; Koeher et al., 2014). From the conceptual framework presented in (Figure 2), different skills required to integrate ICT into teaching and learning processes are defined and presented here below:

- Technological Knowledge (TK): These are skills required to use ICT tools such as computers, projectors, camera, digital videos, white boards, internet and the abilities to use different software programs and many others required to be familiar with ICT use (Koeher et al, 2014).

- Content Knowledge (CK): These are skills related to the subject to be taught. The teaching and learning processes are well favored if the teacher who delivers the content has the knowledge regarding the actual subject to be delivered to learners (Mishra \& Koehler, 2006).

- Pedagogical Knowledge (PK): Teachers are required to have knowledge regarding the teaching and learning processes. These skills include skills to manage classroom, assessing learners, development of lesson plan and following and handle all behaviors shown the learners in learning process (Schmidt et al, 2008).

- Pedagogical Content Knowledge (PCK): Presented in the intersection of content knowledge and pedagogical knowledge. The pedagogical content knowledge illustrates the content knowledge that deals with the teaching process (Shulman, 1986; Koeher et al, 2014).

- Technological Content Knowledge (TCK): Resulted from the combination of Technological knowledge and Content knowledge. Technological content knowledge refers to the knowledge of how technology can create new representations for specific content (Schmidt et al, 2008; Koeher et al, 2014). 


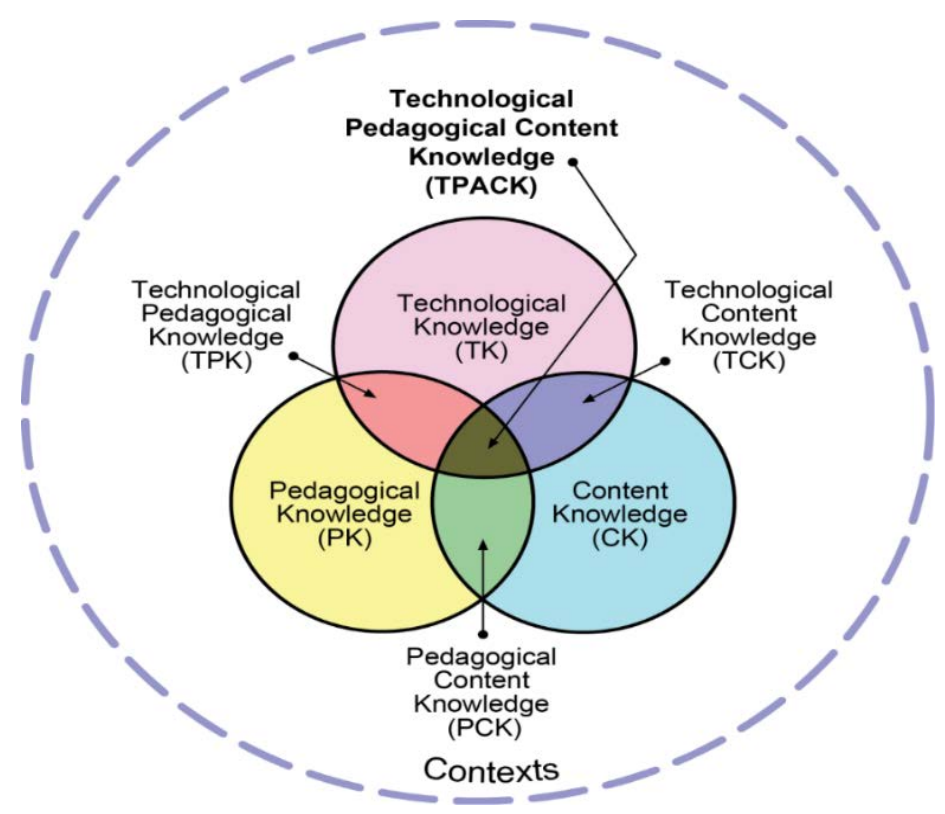

Figure 2. The components of TPACK framework adopted from (Schmidt et al., 2008)

- Technological Pedagogical Knowledge (TPK): Resulted from the combination of Technological knowledge and pedagogical knowledge. This type of knowledge refers to the knowledge of how various technologies can be used in teaching, and to understanding that using technology may change the way teachers deliver the content and influence learners to gain more and more knowledge (Schmidt et al, 2008; Mishra \& Koehler, 2006).

- Technological pedagogical content knowledge (TPACK): Resulted from the intersection of three main diagrams (CK, PK, TK) of knowledge required for integrating ICT into teaching and learning activities. Teachers should have the TPACK in order to be able to conduct effectively the integration of technology into their teaching activities (Schmidt et al., 2008; Koeher et al., 2014; Igbo \& Imo, 2017).

\section{PURPOSE OF THE STUDY}

By introduction of One Lap Top Per Child Program in primary schools of Rwanda, the government was aiming to increase learners' abilities of gaining more information and benefits from ICT application (Rwanda Vision 2020, 2000). Various studies have identified different requirements for better integrating ICT into teaching and learning processes ( Kayisire \&Wei, 2016; Mukama, 2009). The successfulness of ICT integration in primary schools of Rwanda depends largely on teachers' engagement in teaching and learning processes. However, not only being a teachers that allow them to cope with integration of ICT, but also, the availability of necessary requirements, skills required which play a vital role in the integration of ICT into teaching and learning processes (Igbo \& Imo, 2017; Schmidt et al, 2008). This study, aimed to investigate teachers' perceptions on the integration of ICT into teaching and learning processes by implementation of One Lap Per Child Program in primary schools of Rwanda. The study also aimed to find out different necessities required for integrating ICT into teaching and learning processes; contributions of different stakeholders and finally, the study identified challenges that hinder the implementation of the OLPC program into teaching and learning in primary schools of Rwanda. Possible solutions and strategies required to integrate ICT into teaching and learning by implementing successfully the OLPC program in primary schools of Rwanda were suggested in this study.

\section{RESEARCH QUESTIONS}

1. What would be the teachers' perceptions on benefits from the integration of ICT and the implementation of One Laptop Per Child program (OLPC) into teaching and learning processes in primary schools of Rwanda?

2. What would be the necessities to integrate ICT into teaching and learning in primary schools of Rwanda?

3. What are the main challenges in the duration of integrating ICT into teaching and learning processes in primary schools of Rwanda?

4. What would be the stakeholders' contributions in integration ICT through the implementation of One Laptop Per Child program in primary schools of Rwanda? 


\section{MATERIALS AND METHODS}

The nature of this study was qualitative. The qualitative study was found to be important because the researcher was interested to report primary school teachers' perceptions on the integration of ICT and implementation of One Laptop Per Child program to allow learners being familiar with ICT use by gaining more information in learning process (Creswell, 2000). The qualitative data was also relevant because participants were given enough time to discuss and report about their experiences (Denzin \& Lincoln, 2003).

\section{PARTICIPANTS}

All participants in this study were teachers from the primary school. Data were collected from thirty primary teachers in 2016. Teachers were selected from different areas: 10 were primary teachers from the capital city; another 10 were in small cities while the remaining ten primary teachers were selected from rural areas. All the primary teachers were aware about the policy of integrating ICT by implementation of OLPC program. Both male $(60 \%)$ and female $(40 \%)$ teachers participated into study. Only volunteers and interested teachers were considered to participate into the study. The researcher was assisted by two research assistants in order to match all information obtained from different areas.

\section{PROCEDURES}

Data were collected in two phases for each category of participants. In the 1st phase of the research, the researcher and research assistants attended different trainings where it was possible to meet different teachers familiar with ICT Use to collect data from group discussions. The second phase was to conduct in -depth interviews with all volunteers teachers interested to participate in the study. The first phase of this study was mainly focused on answering the third and the forth questions of this study while the first and the second questions were answered by interview conducted later after the group discussions. Regarding group discussion, different groups of ten teachers in each, were grouped together. Teachers were given material to be used while making a draft of what they were identifying to answer question three and four. Data collected in this phase were based on the different group' presentations regarding the challenges that hinder the integration of ICT through the implementation of OLPC program in primary education of Rwanda. Each group representative was given enough time to present orally their findings. During the group presentation the researcher and his research assistants recorded all findings that were presented from the group discussions to be compared and categorized in data analysis. After that, the researcher and his assistants obtained the telephone contact of each interested teacher to participate later in the deep interview in order to get responses regarding questions one and question two. The interview process has taken 15 days because the research was interviewing two teachers per day by the means of mobile telephone. Each teacher was given enough time (20-30minutes) to express him/herself in order get the accurate data. During the interview process data were being recorded for next step of data analysis. All recoded data were analyzed by thematic analysis (Creswell, 2000). The thematic analysis was important because it involves deductive and inductive coding (Boyatzis, 1998). Deductive coding focuses on categories and themes in light of the existing literature, whereas inductive coding focuses on themes and variations that emerge from the data (Altınay-Gazi \& Altınay-Aksal, 2017; Zhou, 2014). The similar findings were grouped together discussed and compared with existing literature in the field.

\section{ETHICAL CONSIDERATION}

The full confidentiality and secrecy were guaranteed to the respondents by the following activities: a) respondents' names could not figurate in the study, b) audio recording c) respondents who were interested to sign the informed consent was allowed to sign and d) finally similar data from different respondents were grouped together and then analyzed.

\section{RESULTS}

Obtained research findings and discussions were based particularly on different concepts related to the research questions. These include teachers' perceptions on ICT benefits for both learners and teachers, requirements to integrate ICT into teaching and learning in primary schools of Rwanda, Challenges to integrate ICT into teachings and learning and the role of educational stakeholders in integrating ICT into teaching and learning processes in primary schools of Rwanda. 


\title{
TEACHERS AND LEARNERS' BENEFITS FROM OLPC PROGRAM
}

The findings resulted from qualitative data collected through interviews and focus group showed the teachers' perceptions towards the integration of ICT into teaching and learning through the implementation of One Laptop per Child program. The results were categorized in two groups named Group 1 [GR1] and Group2 [GR 2]. Data obtained from GR1 and GR2 are presented in the following statements here below:

\begin{abstract}
......ICT was recently introduced in my school, and now OLPC program has started being implemented, my schools was given numerous small laptops for primary schools learners. Only pupils from P4-P6 are given the chance to learn how to use computers. Oh, yes, pupils are benefiting from this project because they are now familiar with ICT' Applications at the earlier stage which will allow them to gain more and more information. We will benefit from this OLPC program because we think that, this new program can help us to send homework to learners by internet. Also interested learners are self-coached in new content, so this help us to help learners who have some knowledge content about the new content. Me and my fellow teachers we will share content, advice and more information. I am normally motivated with this new introduced program [GR1].
\end{abstract}

......Since I started my teaching career, I did not use some advanced technological tools, but I am aware that ICT tools can help me to advance in my career. Learners also can benefit from ICT integration. I am motivated to use these technological tools and I shall have benefit to share advice, content, and experiences with other teachers. I think this new program is helpful, I really want be familiar with ICT use so that I can benefit from this newly introduced program. Pupils are motivated but all of us (teachers and learners) are not normally able to use the computers, only two teachers in my school are able to use computers. I only use ICT for my email account, but I do not use computer for teaching and learning activities [GR2].

The data collected from GR1 and GR2 allowed the researcher to identify two categories of teachers. GR1 are those teachers who are usually using ICT and are aware of how to use ICT tools. GR2 are those teachers who are interested to use ICT because they have heard or acquired the importance of using ICT into teaching and learning processes. Teachers' perceptions on ICT show their interest to integrate ICT into teaching and learning processes. In both categories, teachers believe to benefit from ICT by sharing experiences, advices and expertise. These beliefs of teachers regarding on role of using ICT tools in teaching and learning are quite similar to those of Kayisire \&Wei (2016); Igbo \& Imo (2017), who indicated that teachers had positive attitudes toward ICT, and there was a positive correlation between their attitudes toward ICT and their perceptions of computer attributes. Teachers' interest of integrating ICT bases on that ICT can easily enhance communication between teachers, learners and other stakeholders. (UNESCO, 2015). Similar to the study of Tarus (2015), teachers showed their motivation to use ICT because they can prepare the new content by the means of ICT tools. Teachers also are aware that ICT will help learners to do their self-coaching and that teachers can use technology to illustrate and demonstrate new content. Collected data showed that teachers have positive feelings towards ICT integration into teaching and learning processes in primary schools of Rwanda.

\section{NECESSITIES TO INTEGRATE ICT INTO TEACHING AND LEARNING PROCESSES}

Teachers' perceptions on the requirements required to integrate ICT into teaching and learning felt into three categories of requirements: Here below are statements collected from different group discussions and interviews with primary schools teachers.

\footnotetext{
........The integration of ICT into teaching and learning processes in primary schools is necessary. It would be better if the government provide enough required technological tools such computers, projectors, camera and many others required to disseminate knowledge through ICT applications. It is also good if the government allocate enough infrastructures so that we can have safe place necessary for integrating ICT. Even though we are interesting to use ICT tools to facilitate our learners through teaching and learning processes, many of us are not at the level of being able to use ICT tools. We are lacking technological knowledge and other knowledge required to use ICT tools because it is new for us to use technology in teaching and learning processes.
}

Similar to other existing new researches such those of Tarus (2015), Kayisire \&Wei (2016), Igbo \& Imo (2017), Delport (2016), Egbe et al. (2016), Helm (2015); Kumpel et al., (2015), Mbatha (2016), G. Muhametjanova \& Çagiltay (2012), Ouoba et al. (2016), Porter \& Graham (2016) and Sekoaila et al. (2016); the findings regarding teachers' perceptions to the necessities required to integrate ICT into teaching and learning processes in primary schools of 
Rwanda felt into three categories of requirements. These include: (1) Technological tools, (2) infrastructures such electricity and building and (3) skills necessary to use effectively ICT tools.

\title{
CHALLENGES FACED FOR INTEGRATING ICT INTO TEACHING AND LEARNING
}

Teachers were given the opportunities to illicit all challenges and suggest possible solutions to overcome them. Findings regarding challenges that hinder the integration of ICT into teaching and learning processes by implementation of OLPC program in primary schools of Rwanda were presented in the statement 1 (ST1) and possible suggested solutions were presented in statement 2 (ST2) here below:

....... I was considered to be a good teacher, and I won different prizes of being a good teacher among many others but the introduction of ICT into teaching and learning left me behind because it was the first time to acquire new knowledge related to integration of ICT into teaching and learning. I do not have my own advanced computer also this challenges me. Only the provided computers are small laptops to motivate and facilitate learners being familiar with ICT use, but they are not appropriate for teachers. Sometimes, while teaching, I face some challenges attached to lack of adequate infrastructures. Besides these, also a big number of pupils in the same classroom can't favor teachers to help learners appropriately and others challenges related to my everyday life like the shortage of my salary sometimes discourage to work and be happy to adopt new introduced policies (ST1).

........The government should facilitate teachers to gain more skills required to integrate ICT into teaching and learning process by providing enough trainings or by creating the special formal program to learn how to use ICT into teaching and learning process. We should also require the government aids by giving us more advanced laptops so that we can use and advance our profession through ICT' applications. The government should provide adequate infrastructures by allocating funds to have all required material. It is also good to reduce the teacher-learner ratio to allow the full teachers' assistance provided to learners. The government also should increase our salaries so that we can take the fully engagement in implementing the new policies (ST2).

From above statements, it is seemed that teachers are facing challenges related to (1) lack of adequate skills required to integrate ICT into teaching and learning processes, (2) lack of adequate technological tools, (3) lack of adequate infrastructures, (4) lack of teaching motivation because of their financial constraints. From these above statements teachers suggested that the government should (1) train them to gain the required knowledge, (2) support them by having their own laptops, (3) provide required infrastructures (4) recruit other teachers to reduce teachers-learners ratio and finally (5) increases teachers motivation by reducing all challenges attached to the shortage of financial payments. These findings were also identified in other related studies such as those of Helm (2015), Porter \& Graham (2016), Muhametjanova \& Cagiltay (2016), Shongwe (2015), Tabira \& Otieno (2017) and Jaarsveldt \& Wessels (2015).

\section{ROLE OF EDUCATIONAL STAKEHOLDERS TO INTEGRAT ICT}

Teachers valued the role of different educational stakeholders for successful implementation of new policies regarding the integration of OLPC program in primary schools of Rwanda. The teachers' views on the contributions of different stakeholders in primary school are given here below:

\begin{abstract}
........Oh, yes, teachers would require the partnership between local authorities, parents, NGOs and many others stakeholders to implement OLPC program. Parents should allow learners the time to revise their new content and help them do their homework by communicating to teachers when necessary. Local leaders and parents should participate in preventing drop out and learners' absence so that all learners should be taught and learn together. NGOs and government should facilitate schools by providing different necessities such as computers, trainings for teachers, supporting vulnerable learners and many others possible supports.
\end{abstract}

From above statements it is well observed that teachers' perception towarded the implementation of OLPC program helped them to recognize the contribution of different stakeholders in primary schools. The role of stakeholders within educational activities was also underlined in other recent studies such those of Tarus (2015), Vandeyar (2015), Bornman (2016) and Asongu \& le Roux (2017). 


\section{DISCUSSIONS}

The discussions in this study underlined the purpose and research questions to be answered by this current research. We mainly focused on understanding teachers' perceptions in integrating ICT into teaching and learning by applying the One Laptop Per Child (OLPC) program in primary schools of Rwanda. The responses drawn from the findings are summed up and discussed as follows:

Integration of ICT by implementing the OLPC program in teaching and learning processes in primary schools was found influential to facilitate teachers and learners in Rwanda. Teachers were motivated to use ICT tools because they believe the integration of ICT by implementing OLPC can be one of the effective way to help learners and develop their profession by gaining news skills required for increasing the quality education in primary schools of Rwanda. The findings of this study are aligned with the views presented in other related studies such those of Asongu \& Le Roux (2017), Bornman (2016), Flor (2016), Tabira \& Otieno (2017), Lave \& Wenger (1991), Kozma et al. (2004), Andersson (2006), Harmone \& Jones (1999) and Mukama (2008) who pointed out the role of ICT for teachers and learners and the importance of incorporating ICT into teaching and learning activities. According to Kayisire \&Wei (2016); Igbo \& Imo (2017) it is indicated that teachers had positive attitudes toward ICT, and there was a positive correlation between their attitudes toward ICT and their perceptions of computer attributes. For example, Mukama (2008), in his study has demonstrated and underlined the importance of using ICT between student teachers who, through its implementation can elaborate ideas provided in electronic articles, explain, enrich, or contrast them particularly when they discuss in a language they understand better. The teachers' perceptions towards the benefits of ICT integrations was also underlined by Yidana and Asiedu-Addo (2001), who asserted that ICT literate teachers should play a key role by motivating, inspiring, and exciting learners to cope with these new pedagogical tools. The findings were also in agreement with the study of Koeher et al (2014) and Burkhardt,et al. (2003), who showed that ICT skills are among skills required for $21^{\text {st }}$ century.

Besides the importance of ICT integration into teaching and learning processes, teachers illustrated different requirements to implement successfully this new program of integrating ICT through the implementation of OLPC program. Similarly to the findings of the studies such those of Tarus (2015), Kayisire \&Wei (2016), Igbo \& Imo (2017), Delport (2016), Egbe et al. (2016), Helm (2015), Kumpel et al., (2015), Mbatha (2016), Ouoba et al. (2016), Porter \& Graham (2016) and Sekoaila et al. (2016), the majors requirements to integrate ICT into teaching and learning were identified as the following: The need of technological tools, adequate infrastructures and skills required to integrate ICT into teaching and learning processes. Teachers showed their intentions of needing Technological Pedagogical Content Knowledge (TPACK) similar as quoted in (Mishra \& Koehler, 2006; Schmidt et al, 2008; Koeher et al, 2014). The findings of this study were also supported by the study of Fullan (1993) and Kayisire \&Wei (2016) who argued that teachers cannot provide what they do not have and suggested that teachers must be skilled enough if students have to possess the same characteristics.

Findings regarding challenges that hinder the integration of ICT into teaching and learning in primary schools of Rwanda revealed four major challenges. These include (1) Lack of adequate skills required to integrate ICT into teaching and learning processes; (2) Lack of adequate technological tools; (3) Lack of adequate infrastructures and (4) Lack of teaching motivation attached to teachers' financial payments. These results were found to be in agreement with other recent studies such that of Kayisire \& Wei (2016) who identified external and internal barriers to ICT incorporation. External barriers are classified as shortage of equipment, unreliability of equipment, shortage of technical support and other resource-related whereas organizational culture, teacher-level factors, their beliefs about teaching and openness to change are the internal barriers to ICT incorporation (Kayisire \& Wei, 2016). Many other studies such those of Asongu \& Le Roux (2017), Bornman (2016) and Tabira \& Otieno (2017) reported the shortage of training, shortage of time, and shortage of equipment to be the barriers to technology incorporation.

To solve above statements teachers suggested that the government should: (1) train them to gain the required knowledge, (2) support teachers to have their own laptops and other advanced technological tools, (3) provide required infrastructures and (4) increase teachers' motivation by reducing all challenges attached to the shortage of financial payments. The findings of this study were again supported with the studies such those of Emeh and Agbor (2003) who identified teachers' problems in Nigerian context, and found that in the developing countries teachers were affected by low quality of life, low professional esteem and acceptance, and poor and irregular salary payments compared to the business world. Emeh and Agbor suggested that, in order to prepare and produce teachers who are valid and relevant for information age, the government should be endeavor to re-build teacher self-image, and to stress the cultural framework within which the information age operates' (Emeh \& Agbor,2003). The suggested strategies and solutions were also in agreement with current studies such those of Muhametjanova \& Cagiltay (2016), Shongwe (2015), Tabira \& Otieno (2017) and Jaarsveldt \& Wessels (2015).

Teaching and learning processes are influenced by different elements as suggested by UNESCO (2015) and McIlrath \& Huitt (1995). In the current study, teachers underlined the importance of different stakeholders in integrating ICT by implementing OPLC program. Parents, local leaders, NGOs, Churches, educational planners 
and many others were found to be influential in policy' implementation. Teachers' views on different roles that should be taken by different stakeholders reflected to the teaching and learning model of Mcllrath \& Huitt (1995), who demonstrated the impact of different components on teaching and learning processes. Similar to the studies of Tarus (2015), Roschelle (1992) and Rogoff (1994), the collaboration between stakeholders in teaching and learning activities was found to be influential in integrating ICT into teaching and learning activities of primary schools of Rwanda.

\section{CONCLUSION}

This study enlightened teachers' perceptions for integrating ICT into teaching and learning by implementing OLPC program in primary schools of Rwanda. The program was influential for teachers, learners and other stakeholders of primary schools of Rwanda. In order to be fruitful, through implementation of OLPC program, the integration of ICT is also advised to help teachers acquire different Technological Pedagogical Content Knowledge (TPACK). It would be necessary for all stakeholders to participate into the OLPC program by contributing in solving all challenges encountered in everyday lives within the schools. The findings of this study also identified the importance of different stakeholders, teachers, adequate ICT facilities and Skills required to integrate ICT into teaching and learning processes as proposed by TPACK model.

\section{ACKNOWLEDGEMENT}

The authors acknowledge all respondents who took their time to participate in this study. Authors also acknowledge Shan Liangyan who spent her time to proofread this article and make it readable.

\section{REFERENCES}

Alesandrini, K. (1981). Pictorial-verbal and analytic-holistic learning strategies in science learning. Journal of Educational Psychology, 73(3), 358-368.

Altınay-Gazi, Z., \& Altınay-Aksal, F. (2017). Technology as Mediation Tool for Improving Teaching Profession in Higher Education Practices. Eurasia Journal of Mathematics, Science E Technology Education, 13(3), 803-813. https:// doi.org/10.12973/eurasia.2017.00644a

Andersson S. B. (2006). Newly qualified teachers' learning related to their use of information and communication tech- nology: a Swedish perspective. British Journal of Educational Technology, 37, 665-682.

Asongu, S. A., \& Le Roux, S. (2017). Enhancing ICT for inclusive human development in Sub-Saharan Africa. Technological Forecasting and Social Change, 118, 44-54.

Bornman, E. (2016). Information society and digital divide in South Africa: results of longitudinal surveys. Information, Communication \& Society, 19(2), 264-278.

Boyatzis, R. E. (1998). Transforming qualitative information: Thematic analysis and code development. Sage.

Burkhardt, G., Monsour, M., Valdez, G., Gunn, C., Dawson, M., Lemke, C., Coughlin, E., Thadani, V., \& Martin, C. (2003). 21st century skills: Literacy in the digital age. Retrieved June 10, 2017, from www.ncrel.org/engauge

Creswell, J. W. (2000). Research design. Sage, 1-246. https://doi.org/10.1016/j.math.2010.09.003

Delport, P. M., Von Solms, R., \& Gerber, M. (2016, May). Towards corporate governance of ICT in local government. In IST-Africa Week Conference, 2016 (pp. 1-11). IEEE.

Denzin, N. K., Lincoln, Y. S. (2003). Collecting and interpreting qualitative materials. London: SAGE

Egbe, D. A., \& Mutanga, M. B. (2016, May). Technical sustainability in rural ICT deployments in South Africa. In IST-Africa Week Conference, 2016 (pp. 1-9). IEEE.

Emeh J. U., \& Agbor, C. A. (2003). Teacher education challenges in the age of information technology. Global Journal of Educational Research 2, 7-12.

Farrell, G. (2007). ICT in Education in Rwanda. Retrieved on 30th August, 2017 from https://www.infodev.org/infodevfiles/resource/InfodevDocuments_423.pdf

Fullan, M. (1993). Change Forces. The Falmer Press, London.

Harmon, S. W., \& Jones, M. G. (1999). The five levels of web use in education: Factors to consider in planning online courses. Educational Technology, 39(6), 28-32.

Helm, F. (2015). The Practices and Challenges of Telecollaboration in Higher Education in Europe. Language Learning \& Technology, 19(2), 197-217. 
Igbo, H. U., \& Imo, N. T. (2017). Electronic Information Resource Sharing among University Libraries in Southern Nigeria: Opportunities and Challenges. African Journal of Library Archives and Information Science, 27(1), 7791.

Jaarsveldt, L. C. Van, \& Wessels, J. S. (2015). Information technology competence in undergraduate Public Administration curricula at South African universities. International Review of Admistrative Sciences, 81(2), 412-429. https://doi.org/10.1177/0020852314546584

Kayisire, D., \& Wei, J. (2016). ICT adoption and usage in Africa: Towards an efficiency assessment. Information Technology for Development, 22(4), 630-653.

Koehler, M. J., Mishra, P., Kereluik, K., Shin, T. S., \& Graham, C. R. (2014). Handbook of Research on Educational Communications and Technology (pp. 101-111). New York: Springer Science \& Business Media. https://doi.org/10.1007/978-1-4614-3185-5

Kozma, R., McGhee, R., Quellmalz, E., \& Zalles, D. (2004). Closing the digital divide: evaluation of the world links program. International Journal of Educational Development, 24, 361-381.

Kumpel, E., Peletz, R., Bonham, M., Fay, A., Cock-Esteb, A., \& Khush, R. (2015). When are mobile phones useful for water quality data collection? An analysis of data flows and ICT applications among regulated monitoring institutions in Sub-Saharan Africa. International journal of environmental research and public health, 12(9), 1084610860.

Lave, J., \& Wenger, E. (1991) Situated Learning: Legitimate Peripheral Participation. Cambridge University Press, Cambridge, UK.

Mbatha, B. (2016). Pushing the agenda of the information society: ICT diffusion in selected multipurpose community telecentres in South Africa. Information Development, 32(4), 937-952.

McIlrath, D., \& Huitt, W. (1995, December). The teaching-learning process: A discussion of models. Educational Psychology Interactive. Valdosta, GA: Valdosta State University. Retrieved 20 ${ }^{\text {th }}$ May 2017, from http://www.edpsycinteractive.org/papers/modeltch.html

Mishra, P. \& Koehler, M. J. (2006). Technological pedagogical content knowledge: A framework for integrating technology in teachers' knowledge. Teachers College Records, 108(6), 1017-1054.

Mtebe, J. S., \& Raisamo, R. (2014). Investigating Perceived Barriers to the Use of Open Educational Resources in Higher Education in Tanzania. International Review of Research in Open and Distance Learning, 15(2), 43-66.

Muhametjanova, G., \& Çagiltay, K. (2012, July). Students' and Instructors' Perceptions on Use of Information and Communication Technologies during Instruction in a Kyrgyzstan University. In Advanced Learning Technologies (ICALT), 2012 IEEE 12th International Conference on (pp. 500-502). IEEE.

Mukama, E. (2008). Students' interaction with web-based literature: towards dissolution of language boundaries. International Journal of Knowledge and Learning, 4(5), 478-495.

Mukama, E. (2009). The interplay between learning and the use of ICT in Rwandan student teachers everyday practice. Journal of Computer Assisted Learning, 25(6), 539-548. https://doi.org/10.1111/j.13652729.2009.00326.x

Mukama, E., \& Andersson, S. B. (2007). Change in ICT-based learning environments. Journal of Computer Assisted Learning, 24(2), 156-166.

Ouoba, J., Bissyandé, T. F., \& Béré, C. (2016, October). Towards Smart City Implementations in Sub-Saharan Africa. In Smart City $360^{\circ}$ (pp. 78-90). Springer International Publishing.

Porter, W. W., \& Graham, C. R. (2016). Institutional drivers and barriers to faculty adoption of blended learning in higher education. British Journal of Educational Technology, 47(4), 748-762.

Resta, P. (Ed.). (2002). Information and Communication Technologies in Teacher Education: A Planning Guide. UNESCO, Paris.

Rogoff, B. (1994) Developing understanding of the idea of community of learners. Mind, Culture, and Activity, 1, 209-229.

Roschelle, J. (1992) Learning by collaborating: convergent conceptual change. Journal of the Learning Sciences, 2, 235276.

RwandaVision, 2020. (2000). Ministry of finance and economic planning, republic of Rwanda. Available at http://www.nur.ac.rw/IMG/pdf/Vision_2020. Pdf. Accessed 26 March 2017

Schmidt, D. A., Thompson, A. D., Koehler, M. J., \& Shin, T. S. (2008). Technological Pedagogical Content Knowledge (TPACK): The Development and Validation of an Assessment Instrument for Preservice Teachers, 42(2), 123-149.

Sekoaila, U., \& Adebesin, F. (2016, May). Women in ICT: Barriers to career advancement and strategies for improvement. In IST-Africa Week Conference, 2016 (pp. 1-12). IEEE. 
Shongwe, M. M. (2015). The information technology influence on LIS job descriptions in South Africa. Information Technology for Development, 21(2), 196-204.

Shulman, L. S. (1986). Those who understand: Knowledge growth in teaching. Educational Researcher, 15(2), 4-14.

Stones, E. (1966). An introduction to educational psychology. London: Methuen

Tabira, Y., \& Otieno, F. X. (2017). Integration and implementation of sustainable ICT-based education in developing countries: low-cost, en masse methodology in Kenya. Sustainability Science, 12(2), 221-234.

Tarus, J. K., Gichoya, D., \& Muumbo, A. (2015). Challenges of Implementing E-Learning in Kenya: A Case of Kenyan Public Universities Challenges of Implementing E-Learning in Kenya: A Case of Kenyan Public Universities. International Review of Research in Open and Distance Learning, 16(1), 1-10. https://doi.org/10.19173/irrodl.v16i1.1816

UNESCO. (2003). Developing and Using Indicators of ICT Use in Education. Bangkok: UNESCO Asia and Pacific Regional Bureau for Education.

UNESCO. (2015). ICT in Education in Sub-Saharan Africa, A comparative analysis of basic e - readiness in schools, (25). Retrieved 30th August 2015, from http://uis.unesco.org/sites/default/files/documents/informationand-communication-technology-ict-in-education-in-sub-saharan-africa-2015-en.pdf

Vandeyar, T. (2015). Policy intermediaries and the reform of e-education in South Africa. British Journal of Educational Technology, 46(2), 344-359

Yidana, I., \& Asiedu-Addo, S. K. (2001). The use of information technology in teacher education. Mathematics Connection, 2, 30-33.

Zhou, J. (2015). International students' motivation to pursue and complete a Ph. D. in the US. Higher Education, 69(5), 719-733.

\section{http://www.ejmste.com}

